\title{
Perceptions of water access in the context of climate change by rural households in the Seke and Murewa districts, Zimbabwe
}

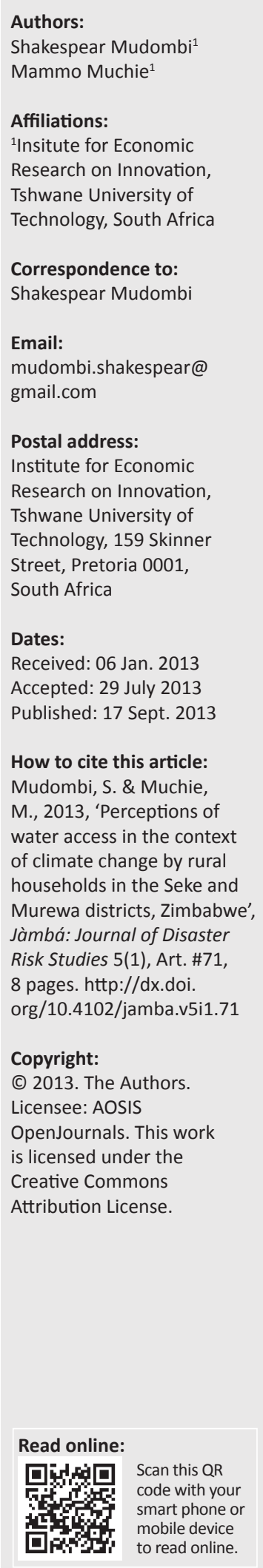

Authors:

Shakespear Mudomb

Tshwane University of

Correspondence to:

Shakespear Mudomb

Email:

mudombi.shakespear@

Institute for Economic

Research on Innovation,

shwane University of

Street, Pretoria 0001

South Africa

Dates:

Accepted: 29 July 2013

How to cite this article: Mudombi, S. \& Muchie, M., 2013, 'Perceptions of water access in the context of climate change by rura Jàmbá: Journal of Disaster Risk Studies 5(1), Art. \#71, 8 pages. http://dx.doi.

Copyright:

(C) 2013. The Authors. is licensed under the Creative Commons Attribution License.
The objective of the study was to assess perceptions of rural household heads with regard to various aspects of water access and climate change, and to evaluate whether there were significant differences in perceptions of respondents from female-headed and male-headed households. The study is based on a cross-sectional survey of 300 respondents conducted in the Seke and Murewa districts of Zimbabwe in 2011. The analysis included mainly descriptive statistics. The majority of both female-headed and male-headed households relied on rainfall for their crops, rivers were cited as the main water source for their livestock and protected wells supplied water for household use. Households experienced water shortages, which were attributed mainly to reduced rainfall. The general perception was that there would be less water available in future, with a greater proportion of female-headed than male-headed households perceiving such difficulties. However, very few respondents indicated that they would consider emigrating, although female-headed households were more likely to consider emigrating than male-headed households. A considerable number of respondents indicated that they did not have any means to overcome the water shortages. This highlights the need for interventions such as training and empowerment of individuals with regard to sustainable water use and management.

\section{Introduction}

Global water resources are limited and unevenly distributed. This is further worsened by the pressures of economic growth, major population increases and climate change (United Nations Educational, Scientific and Cultural Organization [UNESCO] 2006:12). Water is the primary medium through which climate change influences the Earth's ecosystem and thus the livelihood and well-being of societies (United Nations Water n.d.). Climate change has significant impacts on freshwater sources, which affect the availability of water used for domestic and productive tasks (United Nations WomenWatch 2009).

Water is one of several current and future critical issues facing Africa (Bates et al. 2008:79; Intergovernmental panel on Climate Change 2001:521). About 25\% of Africa's population currently experience high water stress and countries that do not currently experience water stress will be at risk of water stress in future (Boko et al. 2007:435). Zimbabwe is currently experiencing water shortages, a situation that is aggravated by frequent droughts (Ministry of Mines, Environment and Tourism 1998). Climate projections for Zimbabwe are for a warmer future climate. Rainfall predictions for the country are less certain, although various models suggest that rainfall patterns are likely to change and extreme events are set to increase; some models predict a $10 \%-20 \%$ decline in rainfall by 2050 (Adaptation Learning Mechanism 2011).

Climate change is often seen as a technical problem that requires technical and scientific solutions, but there are also many social and political aspects to this complex issue (Dankelman 2002:24; Skinner 2011:1; United Nations Development Programme [UNDP] 2009:77). The way households respond to the reduced quantity and quality of water has major implications for long-term sustainability of their livelihoods and the natural environment. Some of the factors that influence the adaptive capacity of individuals and households include income, gender, assets and entitlements, education, access to information, health, access to natural resources, social position, political relationships and government policies (Chindarkar 2012:1; Prowse \& Scott 2008:47; Raleigh, Jordan \& Salehyan n.d.:17).

There is a need to use a 'gender lens' when discussing water access and climate change so as to better understand and ensure that adaptation initiatives consider the gendered differences and do not inadvertently perpetuate inequality (Angula 2010:37; Carvajal-Escobar, Quintero-Angel \& Garcia-Vargas 2008:279; Nair 2012:10; Nelson et al. 2002:56; Parikh 2007:4; Swiss Agency for 
Development and Cooperation 2005:9; UNDP 2009:25; UNDP 2010:6; World Health Organization [WHO] 2011:4). Gender refers to the differences in socially constructed roles and opportunities associated with being a man or a woman and the interactions and social relations between men and women (UNDP 2009:24). Skinner (2011:8) warns that although there is an increasing recognition of the need to look at climate change through a gender lens, too often gender concerns are added into policies or processes as an afterthought.

Gender elements in climate change refers to the different ways in which women and men contribute to climate change, and the differing impacts that climate change has on them (Annecke n.d.; Ongoro \& Ogara 2012:79). Owing to gender roles and differential gendered access to resources, men and women experience climate variability differently and have diverse coping strategies (Lambrou \& Nelson 2010:50). Crow and Sultana (2002:712) identified three ways in which gender relations might influence the social relations of water access: gender-based divisions of work, assets or resource ownership and access, and policy discourse and local norms, which may situate economic uses of water and domestic uses in a specific gender domain.

Most of the past studies have looked at the relationship between gender and water access mainly from the perspective of roles and responsibilities of women and men in accessing water. However, another important gender dimension in the context of climate change, which is often neglected, is how differences between female-headed and male-headed households influence their access to water. Moreover, less attention has been given to analysing their perceptions of water access in the context of climate change. Chagutah (2010:vi) observed that there is a paucity of gender-disaggregated data relating to vulnerability at the community and household levels in Zimbabwe.

It is in this context that this study seeks to contribute to the body of knowledge. The first objective of the study was to evaluate how rural households in the Seke and Murewa districts access water for household use, livestock and crops. The second objective was to assess these households' perceptions on various aspects of current and future water access in the context of climate change and evaluate whether there were significant differences in perceptions of respondents from female-headed and male-headed households.

\section{Research methods}

The study was conducted in the Mashonaland East province of Zimbabwe. In 2002, the total population of Zimbabwe was estimated at 11634663 people, with a total population of about 1127413 people across 309198 households in Mashonaland East (Central Statistical Office 2004). About $90 \%$ of the population in the Mashonaland East province reside in rural areas. The province has 11 districts, from which two (Seke and Murewa) were selected. The two districts have climatic conditions associated with natural region II, with an average annual rainfall of $500 \mathrm{~mm}-700 \mathrm{~mm}$. The amount of rainfall varies across and within the districts, with some parts receiving adequate rainfall whilst others receive inadequate rainfall.

The data were collected using a general household survey conducted between May and August 2011. A multistage sampling approach was used for collecting quantitative data. This technique was considered the most appropriate to use in the study as there were no sampling frames at district level. From each district, three wards were selected, in each ward, five villages were selected, and in each village, 10 households were selected. At village level, the household sampling frame was sourced from the village head and agricultural extension officers. Households were selected systematically, using different sampling intervals for each village depending on the number of households in each village.

The respondents in the study were the household heads. Of the 300 households interviewed in the general household survey in the two districts, 32\% were female-headed whilst $68 \%$ were male-headed households. For both male-headed and female-headed households, the average household size was six members.

The statistical package SPSS was used for data handling and analysis of quantitative data. The analysis included mainly descriptive statistics (frequencies) and tests of differences on various variables between male-headed and female-headed households. Tests for normality of data were conducted using the Kolmogorov-Smirnov test; from the output, all variables had $p$-values $<0.001$. These $p$-values indicated that the variables were not normally distributed and therefore non-parametric tests had to be used (Field 2009:540). The Mann-Whitney test was used to test for differences, as it is closer to the independent samples $t$-test, which is generally used for normally distributed data (ibid). The significance of differences between female-headed and male-headed households was evaluated at three significance levels, namely $10 \%, 5 \%$ and $1 \%$.

\section{Results}

The results are presented in different sections as follows: water sources used by households for household use, crops and livestock; perceptions on current water shortages; perceptions of changes in water availability; perception of future water access, and perceptions of future water shortages and the likelihood to emigrate to other areas.

\section{Water sources for household use, crops and livestock}

The results on water sources used by households are disaggregated by the sex of the household head. The main water source for household use for the majority of households for both female-headed and male-headed households was protected wells (71\% and $72 \%$, respectively; Table 1$)$. This was followed by boreholes, unprotected wells and piped water. None of the households used river water for household use. According to the Mann-Whitney test there 
were no significant differences between female-headed and male-headed households with regard to water sources for household use.

For the majority of households in the study (65\% of femaleheaded and $67 \%$ of male-headed households), the distance to the water source was less than $1 \mathrm{~km}$. About $30 \%$ of femaleheaded and $28 \%$ of male-headed households travelled $1 \mathrm{~km}-$ $2 \mathrm{~km}$ to this water source. Very few households (about $2 \%$ of female-headed households) had to travel further than $3 \mathrm{~km}$ to water sources for household use. There were no significant differences in distance to the water source for household use between female-headed and male-headed households.

The majority of the households cited a river as the water source for livestock ( $63 \%$ of female-headed and $72 \%$ of male-headed households). This was followed by protected wells (28\% of female-headed and $20 \%$ of male-headed households). There were no significant differences between female-headed and male-headed households with regard to water sources for livestock. With regard to distances travelled to a water source for livestock, the majority of female-headed households (49\%) travelled no more than $1 \mathrm{~km}$, whilst about 32\% had access to water sources for livestock within $1 \mathrm{~km}-2 \mathrm{~km}$. For male-headed households, 32\% travelled no more than $1 \mathrm{~km}$ to water sources for livestock, whilst $40 \%$ had access to water sources within $1 \mathrm{~km}-2 \mathrm{~km}$. Generally, a greater proportion of female-headed than male-headed households utilised

TABLE 1: Water sources for household use, livestock and crops.

\begin{tabular}{|c|c|c|c|c|}
\hline \multirow[t]{2}{*}{ Water sources and uses } & \multirow[t]{2}{*}{ Response } & \multicolumn{2}{|c|}{ Household head } & \multirow[t]{2}{*}{$p$-value } \\
\hline & & Female (\%) & Male (\%) & \\
\hline \multirow{5}{*}{$\begin{array}{l}\text { Water source for } \\
\text { household use }\end{array}$} & Piped water & 4 & 4 & \multirow[t]{5}{*}{0.740} \\
\hline & Borehole & 15 & 16 & \\
\hline & Protected well & 71 & 72 & \\
\hline & Unprotected well & 10 & 9 & \\
\hline & River & 0 & 0 & \\
\hline \multirow{4}{*}{$\begin{array}{l}\text { Distance to water source } \\
\text { for household use }\end{array}$} & $0 \mathrm{~km}-1 \mathrm{~km}$ & 65 & 67 & \multirow[t]{4}{*}{0.642} \\
\hline & $1 \mathrm{~km}-2 \mathrm{~km}$ & 30 & 28 & \\
\hline & $2 \mathrm{~km}-3 \mathrm{~km}$ & 3 & 5 & \\
\hline & $>3 \mathrm{~km}$ & 2 & 0 & \\
\hline \multirow[t]{5}{*}{ Water source for livestock } & Piped water & 4 & 1 & \multirow[t]{5}{*}{0.108} \\
\hline & Borehole & 1 & 3 & \\
\hline & Protected well & 28 & 20 & \\
\hline & Unprotected well & 4 & 4 & \\
\hline & River & 63 & 72 & \\
\hline \multirow{6}{*}{$\begin{array}{l}\text { Distance to water source } \\
\text { for livestock }\end{array}$} & $0 \mathrm{~km}-1 \mathrm{~km}$ & 49 & 32 & \multirow[t]{6}{*}{$0.067^{*}$} \\
\hline & $1 \mathrm{~km}-2 \mathrm{~km}$ & 32 & 40 & \\
\hline & $2 \mathrm{~km}-3 \mathrm{~km}$ & 10 & 14 & \\
\hline & $3 \mathrm{~km}-4 \mathrm{~km}$ & 3 & 9 & \\
\hline & $4 \mathrm{~km}-5 \mathrm{~km}$ & 3 & 3 & \\
\hline & $>5 \mathrm{~km}$ & 4 & 2 & \\
\hline Irrigation use & - & 6 & 8 & 0.614 \\
\hline
\end{tabular}

Significance level: *, $10 \% ;{ }^{* *}, 5 \% ;{ }^{* * *}, 1 \%$

TABLE 2: Perceptions on water shortages.

\begin{tabular}{llccc}
\hline Survey question & Response & \multicolumn{2}{c}{ Household head } & \multirow{2}{*}{ p-value } \\
\cline { 3 - 4 } & & Female (\%) & Male (\%) & \\
\hline Do you experience any & Household use & 76 & 65 & $0.046^{* *}$ \\
water shortages & Livestock & 48 & 45 & 0.570 \\
& Crops & 79 & 74 & 0.367 \\
\hline
\end{tabular}

Significance level: ${ }^{*}, 10 \% ;{ }^{* *}, 5 \% ;{ }^{* * *}, 1 \%$ water sources for livestock that were relatively closer to their homes. In other words, they travelled shorter distances. There were significant differences between female-headed and male-headed households with regard to the distance to the water sources for livestock.

With regard to water used for field crops, all the households indicated that they were dependent on rainfall. Very few households used irrigation ( $6 \%$ of female-headed households; $8 \%$ of male-headed households). There were no significant differences in irrigation use between female-headed and male-headed households.

Respondents were asked which members within the household were responsible for the task of fetching water for household use (i.e. whether it was a men-only or women-only task or one shared by both groups). Responses showed that in $54 \%$ of female-headed households it was a women-only task, whilst in $46 \%$ of the households the task was shared between men and women. For male-headed households, $50 \%$ indicated that it was a women-only task, $41 \%$ indicated that it was a task performed by both men and women, and $9 \%$ indicated that it was a men-only task. There were no significant differences with regard to responsibility between female-headed and male-headed households.

\section{Perceptions on current water shortages}

Respondents were asked whether they experienced any water shortages at any period during a year (Table 2).

The majority of respondents indicated that they experienced water shortages for household use (76\% of female-headed and $65 \%$ of male-headed households); these differences were significant. With regard to water shortages for livestock, $48 \%$ of female-headed and $45 \%$ of male-headed households indicated that they experienced water shortages; however, the difference was not significant. With regard to shortages of water for crops, $79 \%$ of female-headed and $74 \%$ of maleheaded households indicated that they experienced water shortages for crops, but the difference was not significant.

Respondents who indicated that they experienced water shortages were asked a subsequent open-ended question related to whether they had any means to overcome the water shortages. About 39\% of female-headed and $43 \%$ of male-headed households indicated that they did not have any means to overcome current and future water shortages. Respondents who indicated that they did have the means to overcome the shortages suggested the following:

- For household use: fetching water from rivers and neighbouring communities; travelling longer distances to get water; installing piped water; drilling boreholes; digging wells; deepening existing wells.

- For crops: early planting; dry planting; planting droughttolerant crops such as small grains; adopting conservation farming; vegetable gardening; reducing water-demanding cropping activities (e.g. horticultural activities); adopting water harvesting techniques; dam construction; irrigation. 
- Other suggestions included educating people about natural resources and water conservation, seeking support from government and other organisations, protecting wetlands, planting trees, stopping stream bank cultivation, and divine intervention (leaving it to God).

\section{Perceptions of changes in water availability for household use, crops and livestock}

Respondents were asked how water availability for household use had changed over time (i.e. comparing past availability with current availability). A greater proportion of respondents indicated that water for household use had generally become less available ( $47 \%$ of female-headed and $40 \%$ of maleheaded households; Table 3). However, some respondents indicated that water for household use had become more available (27\% of female-headed and $32 \%$ of male-headed households), whilst $26 \%$ of female-headed and $29 \%$ of maleheaded households indicated that it had remained the same. Generally, the findings show that a greater proportion of female-headed than male-headed households considered water for household use having become less available, although the difference was not significant.

With regard to water availability for livestock, $43 \%$ of femaleheaded and $42 \%$ of male-headed households indicated a reduced availability, whilst $31 \%$ of female-headed and $28 \%$ of male-headed households indicated an increased availability. The perception amongst $26 \%$ of female-headed and $30 \%$ of

TABLE 3: Perceptions of changes in water availability.

\begin{tabular}{|c|c|c|c|c|}
\hline \multirow[t]{2}{*}{ Survey question } & \multirow[t]{2}{*}{ Response } & \multicolumn{2}{|c|}{ Household head } & \multirow[t]{2}{*}{$p$-value } \\
\hline & & Female (\%) & Male (\%) & \\
\hline \multirow{3}{*}{$\begin{array}{l}\text { How has water } \\
\text { availability changed } \\
\text { over time for } \\
\text { household use? }\end{array}$} & More available & 27 & 32 & \multirow[t]{3}{*}{0.267} \\
\hline & Remained the same & 26 & 29 & \\
\hline & Less available & 47 & 40 & \\
\hline \multirow{3}{*}{$\begin{array}{l}\text { How has water } \\
\text { availability changed } \\
\text { over time for } \\
\text { livestock? }\end{array}$} & More available & 31 & 28 & \multirow[t]{3}{*}{0.860} \\
\hline & Remained the same & 26 & 30 & \\
\hline & Less available & 43 & 42 & \\
\hline \multirow{3}{*}{$\begin{array}{l}\text { How has water } \\
\text { availability changed } \\
\text { over time for crops? }\end{array}$} & More available & 16 & 16 & \multirow[t]{3}{*}{0.968} \\
\hline & Remained the same & 22 & 22 & \\
\hline & Less available & 62 & 62 & \\
\hline \multirow{4}{*}{$\begin{array}{l}\text { Reason for reduced } \\
\text { availability }\end{array}$} & Less rainfall & 81 & 83 & \multirow[t]{4}{*}{0.716} \\
\hline & Fall in the water table & 11 & 11 & \\
\hline & $\begin{array}{l}\text { Breakdown of infrastructure } \\
\text { (for example borehole) }\end{array}$ & 5 & 4 & \\
\hline & Increased water demand & 4 & 3 & \\
\hline
\end{tabular}

Significance level: *, $10 \% ; * *, 5 \% ;{ }^{* * *}, 1 \%$

TABLE 4: Perception of future water access.

\begin{tabular}{llccc}
\hline Future water access for & Response & \multicolumn{2}{c}{ Household head } & \multirow{2}{*}{ p-value } \\
\cline { 2 - 4 } & & Female (\%) & Male (\%) & \\
\hline Household use & Easier & 14 & 21 & $0.064^{*}$ \\
& Remain the same & 35 & 39 & \\
& Difficult & 51 & 41 & \\
Livestock & Easier & 19 & 19 & 0.545 \\
& Remain the same & 29 & 34 & \\
Crops & Difficult & 52 & 47 & \\
& Easier & 9 & 12 & 0.137 \\
& Remain the same & 21 & 28 & \\
& Difficult & 69 & 60 & \\
\hline
\end{tabular}

Significance level: *, $10 \% ;{ }^{* *}, 5 \% ; * * *, 1 \%$ male-headed households was that water availability had remained the same. There were no significant differences in perceptions of changes in water availability for livestock.

With regard to perceptions of changes in water availability for crops, the majority of respondents (62\% of both femaleheaded and male-headed households) indicated that water had become less available (owing to reduced rainfall). Just over a fifth $(22 \%)$ of both female-headed and male-headed households indicated that it had remained the same, whilst $16 \%$ of both female-headed and male-headed households indicated that the availability of water for crops had increased. There were no significant differences with regard to the perception of changes in water availability for crops amongst the respondents.

Respondents were asked to explain why they considered there to be less water available for the various uses. The majority of respondents ( $81 \%$ of female-headed and $83 \%$ of male-headed households) attributed this to reduced rainfall and a fall in the water table $(11 \%$ of both female-headed and male-headed households). The breakdown of infrastructure such as boreholes was also highlighted as contributing to the reduced water availability (5\% of female-headed and $4 \%$ of male-headed households). Increased water demand was cited as a reason by $4 \%$ of female-headed and $3 \%$ of maleheaded households. There were no significant differences with regard to the perceived causes of reduced water availability.

\section{Perception of future water access}

Respondents were asked how they perceived their water access to change in future. With regard to water for household use, a greater percentage of respondents considered their future water access to be difficult, (51\% of female-headed and $41 \%$ of male-headed households; Table 4 ). About 35\% of female-headed and $39 \%$ of male-headed households expected it to remain the same, whilst $14 \%$ of female-headed and $21 \%$ of male-headed households indicated that they expected it to become easier. These different perceptions of female-headed and male-headed households with regard to future water access for household use were significant $(p<0.1)$, with a greater proportion of female-headed than male-headed households expecting it to become difficult.

With regard to future access to water for livestock, 52\% of female-headed and $47 \%$ of male-headed households indicated that they expected it to become difficult. About $29 \%$ of female-headed and $34 \%$ of male-headed households indicated that they thought it would remain the same, whilst $19 \%$ of both female-headed and male-headed households indicated that they expected it to become easier. There were no significant differences in perceptions of future access to water for livestock.

With regard to future water availability for crops, the majority of respondents indicated that they considered water for crops to become less (69\% of female-headed and $60 \%$ of male-headed households). Approximately $21 \%$ of female- 
headed and $28 \%$ of male-headed households expected that it will remain the same, whilst $9 \%$ of female-headed and $12 \%$ of male-headed households indicated that they expected it to increase. There were no significant differences in perceptions of future water availability for crops.

\section{Future water shortages and the likelihood to emigrate}

Migration induced by climate change remains an aspect that requires attention (Chindarkar 2012:5). In this context, respondents were asked whether they would consider emigrating to other areas if they were to experience (worsening) water shortages (Table 5).

Generally, a small percentage of respondents indicated that they would consider emigrating to other areas if (worsened) water shortages were experienced. Only $8 \%$ of femaleheaded and 3\% of male-headed households indicated they would consider emigrating to other areas if they were to experience water shortages for household use in future. With regard to future water shortages for livestock, $7 \%$ of femaleheaded and 3\% of male-headed households indicated that they would consider emigrating to other areas. Concerning future shortages of water for crops, $7 \%$ of female-headed and $6 \%$ of male-headed households indicated that they would consider emigrating to other areas. Although the majority of households indicated their reluctance to emigrate to other areas as a result of water shortages, significant differences were observed if water shortages for household use (at the $5 \%$ level) and livestock (at 10\% level) were to develop in future. However, there were no significant differences between responses from female-headed and male-headed households with regard to the effect of possible future water shortages for crops.

\section{Discussion}

In the Seke and Murewa districts, protected wells were the main water source for household use, rivers for livestock and rainfall for crop farming. Very few households used irrigation to support crop farming. There were no significant differences between female-headed and male-headed households' responses with regard to water sources for the various uses. These findings are in line with those of Dungumaro (2009), who observed no significant differences between male-headed and female-headed households' cited water sources for domestic use in South Africa.

The task of fetching water for domestic use was the exclusive responsibility of women in almost half of both female-headed and male-headed households, whilst in the remainder men

TABLE 5: Possibility of emigrating to other areas owing to future water shortages.

\begin{tabular}{llccc}
\hline Survey question & Response & \multicolumn{2}{c}{ Household head } & \multirow{2}{*}{ p-value } \\
\cline { 3 - 4 } & & Female (\%) & Male (\%) & \\
\hline Would consider emigrating & Household use & 8 & 3 & $0.040^{* *}$ \\
to other areas owing & Livestock & 7 & 3 & $0.053^{*}$ \\
to water shortages for: & Crops & 7 & 6 & 0.532 \\
\hline
\end{tabular}

Significance level: *, $10 \% ;{ }^{* *}, 5 \% ; * * *, 1 \%$ were also involved in this task. There were no significant differences with regard to gender responsibility for this task between female-headed and male-headed households. These findings agree with those of Nyong and Kanaroglou (1999), who found that women were responsible for collecting domestic water in about $48 \%$ of the households in Katarko Village in north-eastern Nigeria. The authors argued that the general belief that women are the main water collectors in rural areas of developing countries did not hold for Katarko. The findings in the current study indicate that although women were generally responsible for fetching water in many households, the situation is changing in some households, with the task being performed by both women and men.

The findings in our study indicate that the majority of both female-headed and male-headed households (more than $60 \%$ ) travelled less than $1 \mathrm{~km}$ to water sources for household use. No significant differences were observed between households with regard to the distance to water sources for household use, although significant differences were observed with regard to the distance to water sources for livestock. On average, male-headed households accessed relatively distant water sources for livestock. In Madagascar, Boone, Glick and Sahn (2011:1845) found that the distance to the available water sources had an important influence on the choice of water source. In the context of climate change, the ability to access distant water sources is important, as climate change will likely affect water quantity and its availability. This might increase the burden of accessing water (Chindarkar 2012:2; Nair 2012:10; Parikh 2007:14; UNDP 2010:6; WHO 2011:14).

The fourth United Nations World Water Development report highlighted water scarcity, deteriorating water quality, the linkages between water and food security, and the need for improved governance as the most significant in the context of gender differences in access to and control over water resources (UNESCO 2012:22). The majority of households in the two districts surveyed in this study indicated that they experienced water shortages. Generally, a greater proportion of female-headed than male-headed households indicated that they experienced water shortages for household use, crops and livestock. However, significant differences were observed only for water shortages for household use. Respondents attributed the general shortage of water to the reduction in rainfall. These findings are in line with those of Angula (2010:29) in the Daures Constituency in Namibia, where both men and women reported that poor rainfall negatively affected the recharge capacity of the aquifers and boreholes in the area.

It is important to note that perceptions regarding water shortages in relation to climate change are not shaped by climate change alone, but that there are also other unfavourable factors that interact with climate variables. Nelson et al. (2002:52) noted that it may be difficult to disentangle the effects of increasing natural hazards, local environmental degradation and long-term climate change. Although the Seke and Murewa districts are not classified as highly water stressed, it 
is difficult to project how their future water access will change. However, according to the perceptions of household heads, it is evident that current climate variability has a marked impact on rural people's access to water; decreased rainfall was ranked as one of the most important factors impacting water availability. These findings agree with those of Quinn et al. (2003), who found that in Tanzania water access was the most frequently mentioned threat to livelihoods and was generally ranked as severe. Angula (2010:28) observed that rainfall is an important determinant of crop harvests, successful livestock farming and better livelihood options.

Respondents generally considered their future water access to become difficult, especially for crop farming. This agrees with a UNESCO report (2012:13) that notes that water availability for agriculture is already limited and uncertain and is going to worsen in many countries. The perceptions of respondents in this study are supported by those of Unganai and Murwira (2010), who observed that changing rainfall patterns and increases in the frequency of droughts and floods were adversely affecting agricultural yields in Zimbabwe.

The current study found significant differences between female-headed and male-headed households with regard to their perceptions of future water access for household use. More female-headed than male-headed households indicated that they expected it to become difficult. In Tanzania, Quinn et al. (2003) also found that women had higher risk indices than men for problems of access to water. Denton (2002:14) stressed that climate change would worsen the difficulties for rural women in Africa as they live mainly in water-stressed areas and are already bearing the brunt of water shortages.

Whilst this study did not focus specifically on the vulnerability of women, literature generally indicates that climate-related disasters have been found to impact women and femaleheaded households more. This is because of their poorer socio-economic situations (lack of assets and arable land) and their depending more on natural resources for their livelihoods. The disparity is exacerbated by unequal access to resources and decision-making processes (Angula 2010:35; Boko et al. 2007:458; Chindarkar 2012:6; Daze, Ambrose \& Ehrhart 2009:8; Ongoro \& Ogara 2012:83; UNDP 2009:27; United Nations WomenWatch 2009; WHO 2011:17).

A study by Horrell and Krishnan (2007:1355) in Zimbabwe found that female-headed households were considerably poorer than their male counterparts. It is the poor and marginalised who have the least capacity or opportunity to prepare for the impacts of a changing climate (Demetriades \& Esplen 2008:24). Studies that were conducted in India indicate that women tend to have much lower access to critical information on weather alerts and cropping patterns, which affects their capacity to respond effectively to climate variability (WHO 2011:4).

The role of migration as an adaptive measure to climate stress has been highlighted in literature (Bardsley \& Hugo 2010:242; Boko et al. 2007:452). Five dimensions of climate change that have a potential effect on the drivers of migration due to their effect on agricultural productivity include:

- a rise in sea level

- change in tropical storm and cyclone frequency or intensity

- increases in temperature

- changes in rainfall

- changes in temperature (Black et al. 2011:s8).

In Mali, Findley (1994:549) found that the majority of families depend on circular migration as a coping strategy to droughts. In the southern Ecuadorian Andes, Gray (2009:466) found that positive environmental characteristics such as good rainfall decreased emigration, whilst negative environmental characteristics increased emigration. The long-term projection and modelling of climate change in the north-eastern region of Brazil by Barbieri et al. (2010) show that predicted climate changes in this region will impact severely on the agricultural sector, which will result in a potential migration push to other regions in the country.

The current study also analysed perceptions of respondents with regard to the likelihood to emigrate to other areas as a result of future water shortages. The impacts of climate change on water access in the Seke and Murewa districts are likely to be strongly influenced by reduced rainfall and associated droughts. McGregor, Marazzi and Mpofu (2011:11) observed that droughts posed more severe human impacts than flooding in Zimbabwe. The findings of our study indicate that a small proportion of both female-headed and male-headed households would consider emigrating to other areas if water shortages worsened in future. These findings are supported by those of McGregor et al. (2011:23), who observed that ecological shocks (which include droughts) did not constitute a key factor in explaining mass migrations from and within Zimbabwe over the last decade; rather, migrations were influenced by multiple interactions of many factors.

Although both female-headed and male-headed households were generally reluctant to emigrate, the slight differences that were observed can be attributed to differences in coping mechanisms adopted by households when faced with water shortages. Personal characteristics, socio-economic status and the presence of barriers and facilitators of movement have an important bearing on migration propensity (Barbieri et al. 2010:367; Black et al. 2011:s10; Gubhaju \& De Jong 2009:52-54). Lilleør and Van den Broeck (2011:s79) argued that a strong effect of climate change on the migration drivers does not automatically translate into a strong effect on migration; although a negative link between rainfall and migration seems to exist, it is unclear what drives that link. Skinner (2011:32) asserted that migration is often used as a strategy of last resort, when all other coping mechanisms have failed.

\section{Conclusion}

This study considered how respondents from female-headed and male-headed households perceived the likely impact of climate change on current and future water availability and 
access for various uses. The majority of both female-headed and male-headed households relied heavily on rainfall for their crops, rivers for their livestock and protected wells for household use. Households in the two districts experienced water shortages and they generally expected that there would be less water available in future. Water shortages were mainly attributed to reduced rainfall. Some respondents indicated that they had various means to overcome current and future water shortages; however, there was a significant proportion of respondents who indicated that they did not have any means to overcome the shortages. This highlights the need for interventions such as training and empowerment of individuals with regard to sustainable water use and management.

The analysis conducted show few significant differences between female-headed and male-headed households with regard to the various issues that were evaluated; the few significant differences that were observed related mainly to water for household use and, in some cases, livestock. If rainfall decreases as projected, the burden of reduced water availability and access is likely to be experienced more by female-headed households. Whilst many respondents expected that their future water access was likely to be constrained, very few respondents indicated that they would consider emigrating to other areas in response, with a slightly larger proportion of female-headed households than maleheaded households likely to consider emigrating. This study tried to analyse perceptions regarding water use in terms of three aspects: household use, livestock and crops. However, the aspects were not analysed in detail and therefore further research is needed, specifically to consider the nexus between gender roles, water access and climate change.

\section{Acknowledgements}

The data were collected during implementation of the ATPS Phase VI Strategic Plan, 2008-2012, funded by ATPS donors, including the Ministerie van Buitenlandse Zaken (DGIS), The Netherlands. The authors wish to thank the ATPS for the financial and technical support during the implementation of the programme.

\section{Competing interest}

The authors declare that they have no financial or personal relationship(s) that may have inappropriately influenced them in writing this article.

\section{Authors' contributions}

S.M. (Tshwane University of Technology) collected the data and wrote the manuscript. M.M. (Tshwane University of Technology) made conceptual contributions to the manuscript.

\section{References}

Adaptation Learning Mechanism, 2011, Climate variability and change in Zimbabwe viewed 21 December 2012, from http://www.adaptationlearning.net/reasearch/ climate-variability-and-change-zimbabwe

Angula, M., 2010, Gender and Climate Change: Namibia Case Study, Heinrich Böll Foundation Southern Africa, Cape Town.
Annecke, W., n.d, 'Gender and climate change adaptation', in Adaptation and beyond (4), viewed 22 May 2013, from http://www.indigo-dc.org/documents/Adaptation andbeyond04small.pdf

Barbieri, A.F., Domingues, E., Bernardo, L., Queiroz, B.L., Ruiz, R.M., Rigotti, J.I. et al., 2010, 'Climate change and population migration in Brazil's Northeast: Scenarios for 2025-2050', Population and Environment 31(5), 344-370. http://dx.doi.org/ 10.1007/s11111-010-0105-1

Bardsley, D.K. \& Hugo, G.J., 2010, 'Migration and climate change: Examining thresholds of change to guide effective adaptation decision-making, Population and Environment 32, 238-262. http://dx.doi.org/10.1007/s11111-010-0126-9

Bates, B.C., Kundewicz, Z.W., Wu, S. \& Palutikof, J.P. (eds.), 2008, Climate Change and Water: Technical Paper of the Intergovernmental Panel on Climate Change, IPCC Secretariat, Geneva.

Black, R., Adger, W.N., Arnell, N.W., Dercon, S., Geddes, A. \& Thomas, D.S.G., 2011 'The effect of environmental change on human migration', Global Environmental Change 21S, S3-S11. http://dx.doi.org/10.1016/j.gloenvcha.2011.10.001

Boko, M., Niang, I., Nyong, A., Vogel, C., Githeko, A., Medany, M. et al., 2007, 'Africa. Climate change 2007: Impacts, adaptation and vulnerability', in M.L. Parry, O.F. Canziani, J.P. Palutikof, P.J. van der Linden \& C.E. Hanson (eds.), Contribution of Working Group II to the Fourth Assessment Report of the Intergovernmental Panel on Climate Change, 2007, pp. 433-467, Cambridge University Press, Cambridge.

Boone, C., Glick, P. \& Sahn, D.E., 2011, 'Household water supply choice and time allocated to water collection: Evidence from Madagascar', Journal of Development Studies 47(12), 1826-1850. http://dx.doi.org/10.1080/00220388.2011.579394

Carvajal-Escobar, Y., Quintero-Angel, M. \& Garcia-Vargas, M., 2008, 'Women's role in adapting to climate change and variability', Advances in Geosciences 14, 277-280. http://dx.doi.org/10.5194/adgeo-14-277-2008

Chagutah, T., 2010, Climate Change Vulnerability and Adaptation Preparedness in Southern Africa: Zimbabwe Country Report, Heinrich Böll Stiftung Southern Africa, Cape Town.

Chindarkar, N., 2012, 'Gender and climate change-induced migration: Proposing a framework for analysis', Environmental Research Letters 7, 1-7. http://dx.doi.org/ 10.1088/1748-9326/7/2/025601

Crow, B. \& Sultana, F., 2002, 'Gender, class and access to water: Three cases in a poor and crowded delta', Society and Natural Resources 15(8), 709-724. http://dx.doi. org/10.1080/08941920290069308

Central Statistical Office, 2004, Census 2002: Provincial Profile - Mashonaland East, Central Statistical Office, Harare.

Dankelman, I., 2002, 'Climate change: Learning from gender analysis and women's experiences of organising for sustainable development', Gender and Development 10(2), 21-29. http://dx.doi.org/10.1080/13552070215899

Daze, A., Ambrose, K. \& Ehrhart, C., 2009, Climate Vulnerability and Capacity Analysis Handbook, 1st edn., CARE International, viewed 10 May 2011, from http://www. careclimatechange.org/cvca/CARE_CVCAHandbook.pdf

Demetriades, J. \& Esplen, E., 2008, 'The gender dimensions of poverty and climate change adaptation', IDS Bulletin 39(4), 24-31. http://dx.doi.org/10.1111/j.1759-5436.2008. tb00473.x

Denton, F., 2002, 'Climate change vulnerability, impacts, and adaptation: Why does gender matter?', Gender and Development 10(2), 10-20. http://dx.doi.org/10.1080/ 13552070215903

Dungumaro, E.W., 2009, 'Availability of domestic water and sanitation in households: A gender perspective using survey data in South Africa', in A. de Sherbiniin, A. Rahman, A. Barbieri, J.C. Fotso \& Y. Zhu (eds.), Urban Population-Environment Dynamics in the Developing World: Case Studies and Lessons Learned, Committee for International Cooperation in National Research in Demography (CICRED), Paris, viewed 13 July 2013, from http://www.ciesin.columbia.edu/repository/pern/papers/ urban pde dungumaro.pdf

Field, A., 2009, 'Discovering statistics using SPSS', 3rd edn., Sage, London.

Findley, S.E., 1994, 'Does drought increase migration? Study of migration from Mali during the 1983-1985 drought', International Migration Review 28(3), 539-553. during the 1983-1985 drought', International Migration
$\mathrm{http}: / / \mathrm{dx}$.doi.org/10.2307/2546820, PMid:12345794

Gray, C.L., 2009, 'Environment, land, and rural out-migration in the Southern Ecuadorian Andes', World Development 37(2), 457-468. http://dx.doi.org/10.1016/j.worlddev. 2008.05.004

Gubhaju, B. \& De Jong, G.F., 2009, 'Individual versus household migration decision rules: Gender and marital status differences in intentions to migrate in South Africa', International Migration 47(1), 31-61. http://dx.doi.org/10.1111/j.14682435.2008.00496.x, PMid:20161187, PMCid:PMC2727691

Horrell, S. \& Krishnan, P., 2007, 'Poverty and productivity in female-headed households in Zimbabwe', Journal of Development Studies 43(8), 1351-1380. http://dx.doi. org/10.1080/00220380701611477

Intergovernmental Panel on Climate Change, 2001, Climate Change 2001: Impacts, Adaptation, and Vulnerability, J.J. McCarthy, O.F. Canziani, N.A. Leary, D.J. Dokken \& K.S. White (eds.), Cambridge University Press, Cambridge.

Lambrou, Y. \& Nelson, S., 2010, Farmers in a changing climate Does gender matter?, Food and Agriculture Organization, Rome.

Lilleør, H.B. \& Van den Broeck, K., 2011, 'Economic drivers of migration and climate change in LDCs', Global Environmental Change 21S, S70-S81. http://dx.doi.org/1 0.1016/j.gloenvcha.2011.09.002

McGregor, J., Marazzi, L. \& Mpofu, B., 2011, Conflict, migration and the environment: The case of Zimbabwe, Government Office for Science, London, viewed 20 July 2013, from http://bis.ecgroup.net/Publications/Foresight/MigrationandGlobal EnvironmentalChange.aspx

Ministry of Mines, Environment and Tourism, 1998, Zimbabwe's initial national communication on Climate change: Prepared for the United Nations Framework Convention on Climate Change, Ministry of Mines, Environment and Tourism, Harare. 
Nair, A., 2012, 'The real fight against climate change: What would woman do?', wH2O: The Journal of Gender \& Water 1(1), 10-11.

Nelson, V., Meadows, K., Cannon, T., Morton, J. \& Martin, A., 2002, 'Uncertain predictions, invisible impacts, and the need to mainstream gender in climate change adaptations', Gender and Development 10(2), 51-59. http://dx doi.org/ 10.1080/13552070215911

Nyong, A.O. \& Kanaroglou, P.S., 1999, 'Domestic water use in rural semiarid Africa: A case study of Katarko village in northeastern Nigeria', Human Ecology 27(4) 537-555. http://dx.doi.org/10.1023/A:1018739910377

Ongoro, E.B. \& Ogara, W., 2012, 'Impact of climate change and gender roles in community adaptation: A case study of pastoralists in Samburu East District, Kenya' International Journal of Biodiversity and Conservation 4(2), 78-89.

Parikh, J., 2007, Gender and Climate Change Framework for Analysis, Policy \& Action UNDP (India), viewed 14 November 2012, from http://www.in.undp.org/content/ dam/india/docs/gnder_cc.pdf

Prowse, M. \& Scott, L., 2008, 'Assets and adaptation: An emerging debate', IDS Bulletin 39(4), 42-52. http://dx.doi.org/10.1111/j.1759-5436.2008.tb00475.x

Quinn, C.H., Huby, M., Kiwasila, H. \& Lovett, J.C., 2003, 'Local perceptions of risk to livelihood in semi-arid Tanzania', Journal of Environmental Management 68, 111-119. http://dx.doi.org/10.1016/S0301-4797(03)00013-6

Raleigh, C., Jordan, L. \& Salehyan, I., n.d., Assessing the Impact of Climate Change on Migration and Conflict, prepared for the Social Dimensions of Climate Change workshop, World Bank, Washington DC.

Swiss Agency for Development and Cooperation, 2005, Gender \& Water: Mainstreaming gender equality in water, hygiene and sanitation interventions, Swiss Agency fo Development and Cooperation, Bern.

Skinner, E., 2011, Gender and Climate Change: Overview Report, (BRIDGE DevelopmentGender), Institute of Development Studies, Brighton.
United Nations Water, n.d., 'Climate change adaptation: The pivotal role of water', policy brief, viewed 10 November 2012, from www.unwater.org

United Nations WomenWatch, 2009, Women, gender equality and climate change fact sheet, viewed 16 May 2013, from http://www.un.org/womenwatch/feature/ climate_change/

United Nations Development Programme (UNDP), 2009, Resource guide on gender and climate change, United Nations Development Programme, viewed 22 May 2013 from http://www.undp.org/content/dam/aplaws/publication/en/publications/ womens-empowerment/resource-guide-on-gender-and-climate-change/ Resource.pdf

United Nations Development Programme (UNDP), 2010, Gender, climate change and community-based adaptation, United Nations Development Programme, New York.

United Nations Educational, Scientific and Cultural Organization (UNESCO), 2006, The United Nations World Water Development Report 2: Water, a shared responsibility: Executive summary, United Nations Educational, Scientific and Cultural Organization, viewed 15 May 2013, from http://www.unesco.org/new/ en/natural-sciences/environment/water/wwap/wwdr/wwdr2-2006/

United Nations Educational, Scientific and Cultural Organization (UNESCO), 2012, The United Nations World Water Development Report 4: Managing Water under uncertainty and risk: Executive summary, United Nations Educational, Scientific and Cultural Organization, Paris, viewed 15 May 2013, from http://www.unesco. org/new/en/natural-sciences/environment/water/wwap/wwdr/wwdr4-2012/

Unganai, L.S. \& Murwira, A., 2010, 'Challenges and opportunities for climate change adaptation among smallholder farmers in southeast Zimbabwe', paper presented at the 2nd International Conference: Climate, Sustainability and Development in Semi-arid Regions, Ceará Convention Center, Fortaleza, 16-20 August.

World Health Organization (WHO), 2011, Gender, climate change and health, World Health Organization, viewed 10 May 2013, from http://www.who.int/globalchange/ publications/reports/gender_climate_change/en/ 